\title{
MPOWER, needs and challenges: trends in the implementation of the WHO FCTC in the Eastern Mediterranean Region
}

Gholamreza Heydari ${ }^{1}$, Ghazi Zaatari ${ }^{2}$, Jawad A. Al-Lawati ${ }^{3}$, Fatimah El-Awa ${ }^{4}$ and Heba Fouad 4

${ }^{1}$ Tobacco Prevention \& Control Research Center, National Research Institute of TB \& Lung Diseases, Shahid Beheshti University of Medical Sciences, Tehran, Islamic Republic of Iran (Correspondence to: Gholamreza Heydari: ghrheydari@yahoo.com). ${ }^{2}$ Department of Pathology and Laboratory Medicine, American University of Beirut, Beirut, Lebanon. ${ }^{3}$ Directorate-General of Primary Health Care, Ministry of Health, Muscat, Oman. ${ }^{4}$ Tobacco Free Initiative, World Health Organization, Regional Office for the Eastern Mediterranean, Cairo, Egypt.

\begin{abstract}
Background: WHO MPOWER aims to help countries prioritize tobacco control measures in line with the WHO Framework Convention on Tobacco Control.

Objectives: This paper assessed the progress and challenges in implementing the 6 priority policies of MPOWER in countries of the WHO Eastern Mediterranean Region since 2011.

Methods: A checklist was developed and scores assigned based on the MPOWER indicators (maximum score 37). MPOWER data for the Region in the 2015 and 2017 tobacco control reports were extracted and scored. Data from similar analyses for 2011 and 2013 were also included. Countries were ranked by scores for each indicator for 2015 and 2017 and for overall scores for 2011 to 2017.

Results: The Islamic Republic of Iran, Egypt and Pakistan had the highest scores in 2015 (33, 29 and 27 respectively) and the Islamic Republic of Iran, Pakistan and Yemen had the highest scores in 2017 (34, 31 and 27 respectively). The indicators with the highest and lowest combined score for all countries were for advertising bans and compliance with smoke-free policies: 67 and 18 respectively in 2015, and 73 and 15 respectively in 2017. Most countries (15/22) had higher total scores in 2017 than 2015: Afghanistan, Bahrain and Syrian Arab Republic had the greatest increases. The total score for the Region increased from 416 out of a maximum score of 814 in 2011 to 471 in 2017.
\end{abstract}

Conclusions: Although notable achievements have been made in the Region, many challenges to policy implementation remain and require urgent action by governments of the countries of the Region.

Keywords: Tobacco; smoking; media; noncommunicable diseases; control

Citation: Heydair G, Zaatari G, Al-Lawati J, El-Awa F, Fouad H. MPOWER, needs and challenges: trends in the implementation of the WHO FCTC in the Eastern Mediterranean Region. East Mediterr Health J. 2018;24(1):63-71. https://doi.org/10.26719/2018.24.1.63

Received: 22/08/17; accepted: 07/11/17

Copyright (C) World Health Organization (WHO) 2018. Some rights reserved. This work is available under the CC BY-NC-SA 3.o IGO license (https:// creativecommons.org/licenses/by-nc-sa/3.o/igo)

\section{Introduction}

The WHO Framework Convention on Tobacco Control (WHO FCTC) is the first international treaty to provide new legal dimensions for international health cooperation in combating the global tobacco epidemic (1).

The Eastern Mediterranean Region (EMR) of the World Health Organization (WHO) consists of 22 high, middle- and low-income countries. Tobacco use is one of the greatest public health challenges facing this Region. Smoking rates among men are high and are projected to increase. Furthermore, EMR is one of two WHO regions with the fastest growing consumption of tobacco products and where the prevalence of use is expected to increase $25 \%$ by the year 2025 , compared with a decrease in Asia, North America and Europe (2). There is a need, therefore, for comprehensive tobacco control programmes $(3,4)$. A major barrier however to implementing tobacco control programmes worldwide is the tobacco industry, which typically uses its financial power to expand its production, distribution and sale of tobacco products, and to influence policy-makers (2).
In 2008, WHO introduced a package of measures under the acronym of MPOWER with the aim of helping Member States to prioritize tobacco control measures while implementing the various provisions of the WHO FCTC with the ultimate aim of reducing the global morbidity and mortality from tobacco use. This package focuses on 6 evidence-based measures that have been found to have the greatest effect on reducing tobacco consumption, namely: Monitoring tobacco use and prevention policies; Protecting people from tobacco smoke; Offering help to quit tobacco use; Warning about the dangers of tobacco; Enforcing bans on tobacco advertising, promotion and sponsorship; and Raising taxes on tobacco (2). Global experience shows that implementation of these measures reduces tobacco consumption and its harmful health effects (5-7).

WHO published 4 reports on the global tobacco epidemic in 2011, 2013, 2015 and 2017, which included data on the activities of the EMR countries in relation to these 6 policies (8-11). Two studies, based on the 2011 and 2013 WHO MPOWER reports, showed different levels of implementations of the 6 elements of 
MPOWER $(12,13)$. For example, the lack of adherence to the smoking ban in public places was alarmingly high. The studies also demonstrated the poor compliance of the tobacco industry with tobacco control laws, and the sale of tobacco products is still almost unregulated. This contrasts with the experiences in other WHO regions where implementation has been better than the EMR (14-16).

Lessons can be learned from 10 years of implementing WHO FCTC and the demonstrated benefit in combating noncommunicable diseases $(17,18)$. Cairney and Mamudu (19) report that the best approach to tobacco control in a country requires specific policy processes, namely: the department of health takes the policy lead; tobacco is 'framed' as a public health problem; public health groups are consulted at the expense of tobacco control interests; socioeconomic conditions are conducive to policy change; and the scientific evidence is 'set in stone' within governments. No country can meet all these requirements in a short period and there is a wide gap between the expectations of implementing such programmes and the actual situation in many countries, particularly in the EMR. In 2016 and 2017, 2 studies showed that the WHO FCTC implementation in the Region had not improved greatly over the past 6 years $(20,21)$; countries had failed to adopt stronger and more effective policies; and reinforce the already existing laws.

Ourstudy therefore aimed to compare the performance of EMR countries over time in implementation of MPOWER policies, and discuss some of the challenges facing the countries in adopting these effective measures.

\section{Methods}

This study was conducted during May-September 2017. Published literature, official reports on MPOWER and communications with regional experts in the field of tobacco control were the source of our data. Two researchers searched and summarized the papers and reports, screened studies, extracted data independently and resolved any discrepancies under the supervision of the first author. The checklist was designed previously $(12,13)$ by Iranian and international tobacco control specialists and contained 10 indicators based on the main elements of MPOWER [Monitoring, Smoke-free policies, Cessation programmes, Warnings (health warning on cigarette packets, and mass media campaigns), Advertising bans, and Taxation], and 3 other MPOWER indicators: smoking prevalence, smoke-free policy compliance and advertising ban compliance. The cut-offs were set according to the scoring of the indicators in the 2015 Report on the Global Tobacco Epidemic (8). Seven indictors had 5 options and we assigned a score of o up to a maximum of $4 ; 3$ indictors had 4 possible options and were assigned a score of 0 up to a maximum of 3 . Higher scores indicate better level of implementation of MPOWER policies. Thus, the maximum possible score was 37 (Table 1). If data were not available for an indicator, it was scored as zero. As with the two previous studies $(12,13)$, two trained assessors conducted the assessment (correlation coefficient between them $=0.8$ ). Data entry was done independently by the first assessor and

Table 1 Matrix used to assess tobacco control in EMR countries based on the 2015 WHO MPOWER report (8)

\begin{tabular}{|c|c|}
\hline Indicator & Score \\
\hline Adult daily smoking prevalence & 4 \\
\hline Estimates not available & 0 \\
\hline$>30 \%$ & 1 \\
\hline $20-29 \%$ & 2 \\
\hline $15-19 \%$ & 3 \\
\hline$<15 \%$ & 4 \\
\hline Monitoring: prevalence data & 3 \\
\hline No known or recent data or data that are not both recent and representative & 0 \\
\hline Recent and representative data for either adults or adolescents & 1 \\
\hline Recent and representative data for both adults and adolescents & 2 \\
\hline Recent, representative and periodic data for both adults and adolescents & 3 \\
\hline Smoke-free policies (protecting people from second-hand smoke) & 4 \\
\hline Data not reported & 0 \\
\hline Up to 2 public places completely smoke free & 1 \\
\hline 3-5 public places completely smoke free & 2 \\
\hline 6 or 7 public places completely smoke free & 3 \\
\hline All public places completely smoke free & 4 \\
\hline Cessation programmes & 4 \\
\hline Data not reported & 0 \\
\hline None & 1 \\
\hline
\end{tabular}




\begin{tabular}{|c|c|}
\hline Indicator & Score \\
\hline Nicotine replacement therapy and/or some cessation services (neither cost-covered) & 2 \\
\hline Nicotine replacement therapy and/or some cessation services ( $\geq 1$ of which is cost-covered) & 3 \\
\hline National quit line, and both nicotine replacement therapy and some cessation services cost-covered & 4 \\
\hline Health warnings (on cigarette packages) & 4 \\
\hline Data not reported & 0 \\
\hline No warnings or small warnings & 1 \\
\hline Medium-size warnings missing some appropriate characteristics & 2 \\
\hline Medium-size warnings with all appropriate characteristics & 3 \\
\hline Large warnings with all appropriate characteristics & 4 \\
\hline Mass media warnings through anti-tobacco campaigns & 4 \\
\hline Data not reported & 0 \\
\hline No campaign conducted & 1 \\
\hline Campaign conducted with 1-4 appropriate characteristics & 2 \\
\hline Campaign conducted with 5-6 appropriate characteristics & 3 \\
\hline Campaign conducted with all appropriate characteristics & 4 \\
\hline Ban on tobacco advertising, promotion and sponsorship & 4 \\
\hline Data not reported & 0 \\
\hline Complete absence of a ban in print media & 1 \\
\hline Ban on national television, radio and print media only & 2 \\
\hline $\begin{array}{l}\text { Ban on national television, radio and print media as well as on some but not all other forms of direct and/or indirect } \\
\text { advertising }\end{array}$ & 3 \\
\hline Ban on all forms of direct and indirect advertising & 4 \\
\hline Tax on tobacco products & 4 \\
\hline Data not reported & 0 \\
\hline$\leq 25 \%$ of retail price is tax & 1 \\
\hline $26-50 \%$ of retail price is tax & 2 \\
\hline $51-75 \%$ of retail price is tax & 3 \\
\hline$>75 \%$ of retail price is tax & 4 \\
\hline Compliance with bans on advertising & 3 \\
\hline Complete compliance (8/10 to $10 / 10)$ & 3 \\
\hline Moderate compliance (3/10 to $7 / 10$ ) & 2 \\
\hline Minimal compliance (o/10 to $2 / 10$ ) & 1 \\
\hline Not reported & 0 \\
\hline Compliance with smoke-free policies & 3 \\
\hline Complete compliance (8/10 to $10 / 10)$ & 3 \\
\hline Moderate compliance (3/10 to $7 / 10$ ) & 2 \\
\hline Minimal compliance (o/10 to $2 / 10$ ) & 1 \\
\hline Not reported & 0 \\
\hline Total & 37 \\
\hline
\end{tabular}

was checked by the second. The principal investigator randomly selected 2 or 3 of the data entered to monitor the ratings.

\section{Results}

Countries were ranked by scores for each indicator for 2015 and 2017 as shown in Tables 2 and 3 respectively. The highest scores were attained by Egypt, the Islamic Republic of Iran and Pakistan (scores 33, 29 and 27 respectively) in 2015; and Islamic Republic of Iran,
Pakistan and Yemen (scores 34, 31 and 27 respectively) in 2017, while the score for Somalia was 4 in 2015 and 7 in 2017. Thirteen countries did not report adult daily smoking prevalence in 2015, which had decreased to 8 countries in 2017. The indicators with the highest and lowest combined score for all countries were for advertising bans and compliance with smoke-free policies: 67 and 18 respectively in 2015, and 73 and 15 respectively in 2017. Most countries (15/22) had higher total scores in 2017 than 2015, with the greatest increases seen in 


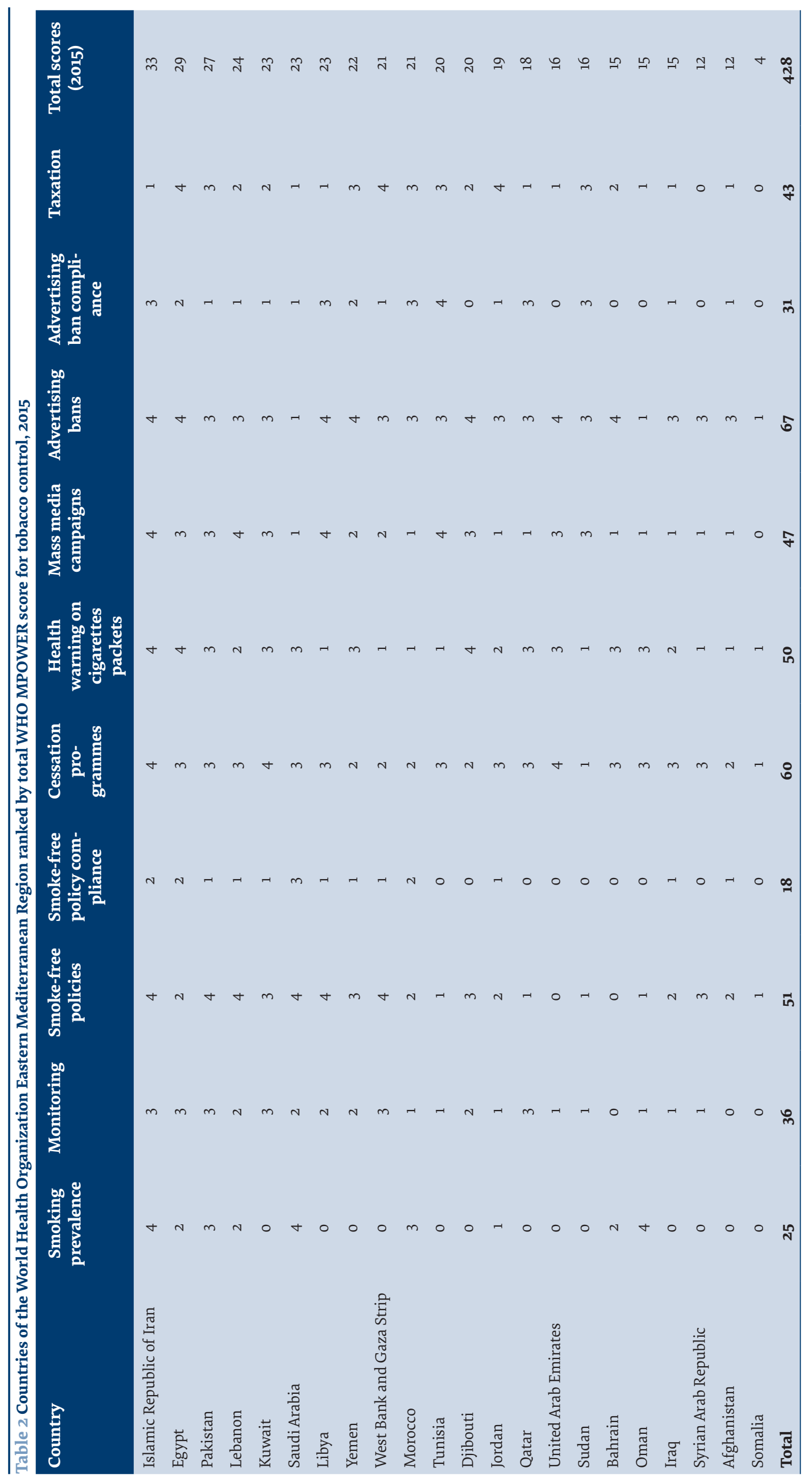




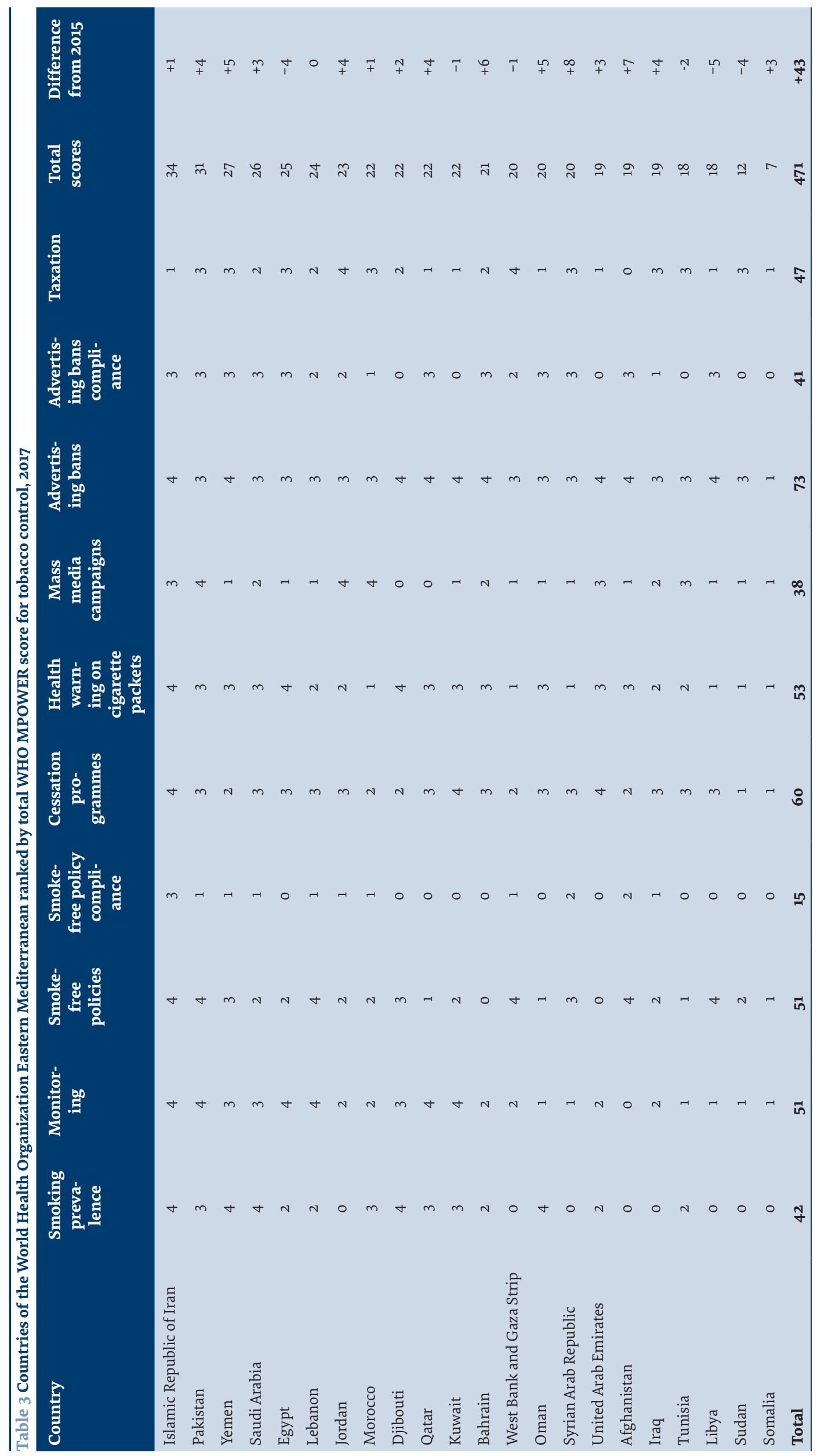


Afghanistan, Bahrain and the Syrian Arab Republic. However, 5 countries had lower scores, including Egypt, Libya and Sudan.

Table 4 shows the total scores for the countries for 2011, 2013, 2015 and 2017. The total score for the Region increased from 416 in 2011 to 471 in 2017. The Islamic Republic of Iran had the highest scores in the 4 years the MPOWER data were analysed. Afghanistan, Lebanon, Pakistan, Saudi Arabia and Yemen showed the biggest increase in their total scores in this time.

\section{Discussion}

From our assessment of the implementation of the MPOWER package in EMR countries over a 7-year period, it is clear that the overall implementation of the FCTC in the EMR remains suboptimal. Some countries have improved their scores in tobacco control while others have failed to show substantial improvement. From 2015 to 2017, the scores of Pakistan, Yemen and Saudi Arabia and Yemen increased and they ranked second, third and fourth in 2017, while the scores of Libya and Sudan were among the lowest. Egypt's overall score decreased and its ranking dropped, but it still had the fifth highest score of the EMR countries. The scores of Afghanistan, Bahrain, Djibouti, Iraq, Jordan, Morocco, Oman, Qatar,
Somalia, Syrian Arab Republic and United Arab Emirates also all increased from 2015 to 2017. More tobacco control programmes have recently been introduced in the EMR $(20,21)$, but they need more time for their effectiveness to be felt.

It is therefore important that EMR countries, particularly those with a decrease in their scores from 2015, to re-examine their performance in order to have stronger national tobacco control plans that incorporate the 6 key policies of MPOWER. In 2006, Joossens and Raw compared tobacco control scores in European countries (22). The same methodology was followed to compare the 22 EMR countries; the study showed Egypt, Jordan and the Islamic Republic of Iran had the highest scores (20). Two previous studies which compared tobacco control programmes among EMR countries and based on the WHO MPOWER reports were published in 2011 and 2013 $(12,13)$. These used the same checklist and scoring system and so offered an opportunity to monitor trends in the increase or decrease of tobacco control indicators from 2011. Comparing the total scores of EMR countries in 2011, 2013 and 2015, we found a 25-point decrease in 2015 compared with 2013 in contrast to the 37-point increase in 2013 compared with 2011. Of particular importance is the fact that tobacco taxation programmes have been

Table 4 Trend in WHO MPOWER scores in tobacco control based on WHO tobacco control reports in Eastern Mediterranean Region countries (8-11)

\begin{tabular}{|c|c|c|c|c|}
\hline Country & $\begin{array}{c}\text { Total score } \\
2017\end{array}$ & $\begin{array}{c}\text { Total score } \\
2015\end{array}$ & $\begin{array}{c}\text { Total score } \\
2013\end{array}$ & $\begin{array}{c}\text { Total score } \\
2011\end{array}$ \\
\hline Islamic Republic of Iran & 34 & 33 & 31 & 29 \\
\hline Pakistan & 31 & 27 & 21 & 20 \\
\hline Yemen & 27 & 22 & 17 & 17 \\
\hline Saudi Arabia & 26 & 23 & 23 & 19 \\
\hline Egypt & 25 & 29 & 28 & 28 \\
\hline Lebanon & 24 & 24 & 26 & 17 \\
\hline Jordan & 23 & 19 & 22 & 21 \\
\hline Morocco & 22 & 21 & 17 & 17 \\
\hline Djibouti & 22 & 20 & 25 & 20 \\
\hline Qatar & 22 & 18 & 21 & 18 \\
\hline Kuwait & 22 & 23 & 28 & 21 \\
\hline West Bank and Gaza Strip & 20 & 21 & 25 & 20 \\
\hline Oman & 20 & 15 & 21 & 16 \\
\hline Syrian Arab Republic & 20 & 12 & 17 & 18 \\
\hline United Arab Emirates & 19 & 16 & 17 & 24 \\
\hline Bahrain & 21 & 15 & 22 & 21 \\
\hline Afghanistan & 19 & 12 & 13 & 9 \\
\hline Tunisia & 18 & 20 & 21 & 17 \\
\hline Iraq & 19 & 15 & 18 & 17 \\
\hline Libya & 18 & 23 & 22 & 21 \\
\hline Sudan & 12 & 16 & 13 & 19 \\
\hline Somalia & 7 & 4 & 6 & 7 \\
\hline Total scores & 471 & 428 & 454 & 416 \\
\hline
\end{tabular}


unsuccessful, even in countries with high overall scores, such as the Islamic Republic of Iran. Ten of the 22 EMR countries were unsuccessful in implementing a tobacco taxation programmes during 2011 to 2015.

All countries need to increase taxation rates to improve the overall performance in effective tobacco control measures. Another example is Egypt, which had a high overall score in 2017 but did not score well in smokefree policies; consequently, more effective reinforcement measures need to be taken. The 2017 data show some challenges in implementing MPOWER policies in certain countries; for example in Kuwait and Saudi Arabia there was a decrease in compliance with smoke-free policies. At the same time, other policies remain unchanged in the countries, such as the inclusion of graphic health warnings on cigarette packets. There is also little steady progress in implementation of other policies, for example the policy on raising taxes. Some countries have gone below the $75 \%$ level of tax and, while some countries increased taxes, they did not reach the highest level, which was reported in a previous analysis $(23,24)$. It is important that countries of the Region not only move forward and not backwards in policy-making, but also aim for the highest policy level, which is the most effective.

This study has some limitations. The MPOWER reports do not refer specifically to waterpipe and other forms of tobacco smoking. Political, social and economic variables that support or act as barriers to tobacco control were not investigated in this study. These factors should be investigated in future studies. The interference of the tobacco industry with the implementation of the control programmes is not well reflected in such surveys. It is well known that the tobacco industry typically uses its large profits to expand its production, distribution and sale of tobacco products as well to influence policymakers in order to impede tobacco control programmes (2).

Conclusion, EMR countries have introduced tobacco control laws after ratifying/acceding to the WHO FCTC, but there has been variable commitment by governments and policy-makers in enacting and reinforcing laws that would lead to effective control measures as assessed by the implementation of MPOWER policies. Although remarkable achievements have been made over the past 7 years, many challenges remain. To overcome them and catch up with the progress of other WHO regions, stronger measures need to be implemented and reinforced as part of comprehensive national plans that take into consideration all social and economic variables. A better outcome can be achieved by greater coordination and cooperation between the countries of the Region to draw up common control strategies. This has already been done successfully in other WHO regions in their fight against the global tobacco epidemic, as for example in the European region (25).

Funding: None.

Competing interests: None declared

\section{Programme MPOWER - besoins et défis : tendances dans la mise en œuvre de la Convention-cadre de l'OMS pour la lutte antitabac dans la Région de la Méditerranée orientale}

\section{Résumé}

Contexte : Le programme MPOWER de l'OMS vise à aider les pays à accorder la priorité aux mesures de lutte antitabac, conformément à la Convention-cadre de l'OMS pour la lutte antitabac.

Objectif : La présente étude a évalué les progrès et les défis de la mise en œuvre des six politiques prioritaires du programme MPOWER dans les pays de la Région OMS de la Méditerranée orientale depuis 2011.

Méthodes: Une liste de contrôle a été mise au point et des scores ont été assignés sur la base des indicateurs MPOWER (score maximum de 37). Des données sur le programme MPOWER dans la Région en 2015 et en 2017 publiées dans des rapports sur la lutte antitabac ont été extraites et se sont vues attribuer une note. Des données issues d'analyses similaires pour les années 2011 et 2013 ont également été incluses. Les pays ont été classés selon les notes attribuées pour chaque indicateur pour 2015 et 2017, et pour l'ensemble des scores pour 2011 et 2017.

Résultats : La République islamique d'Iran, l'Égypte et le Pakistan ont obtenu les scores les plus élevés pour 2015 (33, 29 et 27 respectivement), et la République islamique d'Iran, le Pakistan et le Yémen ont obtenu les scores les plus élevés pour 2017 (34, 31 et 27 respectivement). Les indicateurs comportant les scores combinés les plus élevés et les plus bas pour l'ensemble des pays concernaient les interdictions de publicité et la conformité avec les politiques non-fumeur en 2015 (67et 18 respectivement) et en 2017 (73 et 15 respectivement). La plupart des pays (15/22) ont obtenu des scores totaux plus élevés en 2017 qu'en 2015 : l'Afghanistan, Bahreïn et la République arabe syrienne, affichaient les augmentations les plus importantes. Le score total pour la Région a connu une augmentation, passant de 416 pour un score maximum de 814 en 2011, à 471 en 2017.

Conclusions : Bien que des réalisations considérables soient à noter dans la Région, de nombreux défis entravant la mise en œuvre des politiques demeurent et requièrent une intervention de toute urgence au niveau des gouvernements des pays de la Région. 


\section{مبادرة التحرّر من التبغ، الاحتياجات والتحديات: الاتجاهات السائدة في تنفيذ اتفاقية منظمة الصحة العالمية الإطارية

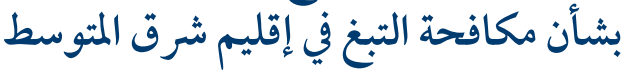

غلام رضا حيدري، غازي زعتري، جواد بن أحمد اللواتي، فاطمة العوا، هبة فؤاد

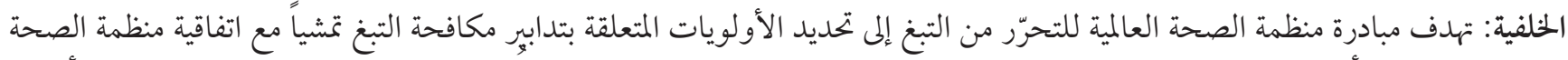

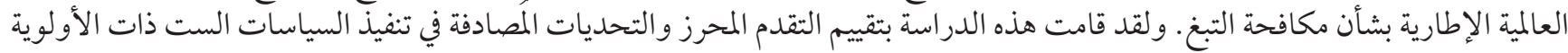

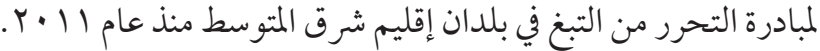

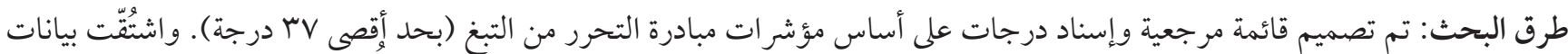

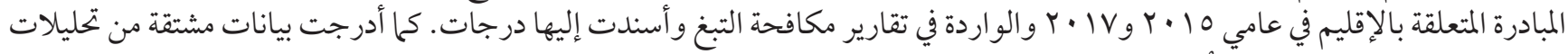

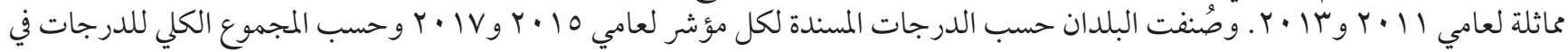

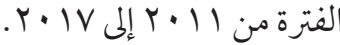

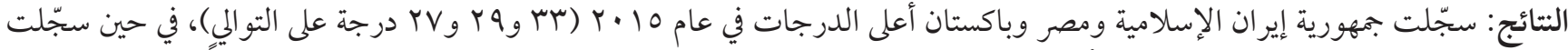

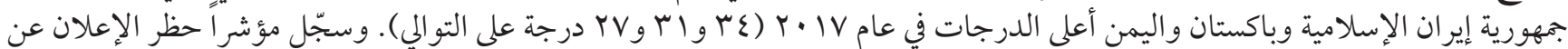

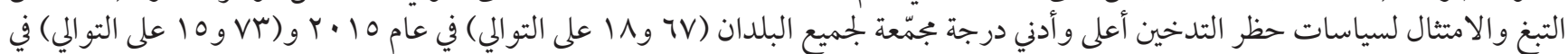

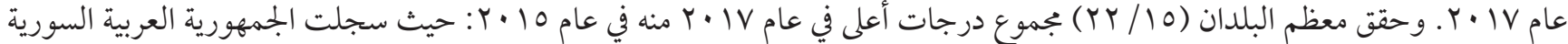

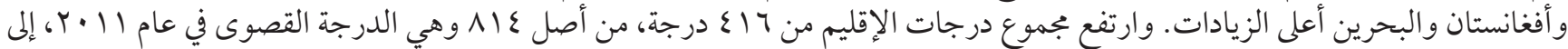

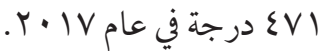

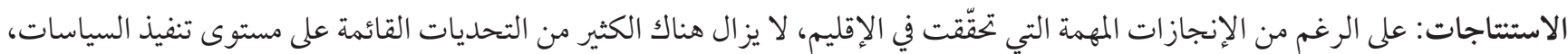
وهو ما يتطلب اتخاذ إجراءات عاجلة من الإزات جانب حكومات التمات دول الإقليم.

\section{References}

1. WHO Framework Convention on Tobacco Control. Geneva: World Health Organization; 2003 (http://www.who.int/fctc/text_ download/en/, accessed 15 May 2017).

2. WHO global report on trends in prevalence of tobacco smoking 2000-2025. Geneva: World Health Organization; 2015 (http:// www.who.int/tobacco/publications/surveillance/reportontrendstobaccosmoking/en/index4.html, accessed 11 January 2018).

3. Levine R, Kinder M. Millions saved: proven success in global health. Washington DC: Routledge; 2006.

4. GBD 2015 Eastern Mediterranean Region Cancer Collaborators, Fitzmaurice C. Burden of cancer in the Eastern Mediterranean Region, 2005-2015: findings from the Global Burden of Disease 2015 Study. Int J Public Health. 2017 Aug 3. http://dx.doi. org/10.1007/s00038-017-0999-9 PMID:28776254

5. Guindon GE, Boisclair D. Past, current and future trends in tobacco use. Washington DC: World Bank; 2003 (http://documents. worldbank.org/curated/en/374771468128405516/pdf/292650Guindon1Past1ocurrent1owhole.pdf, accessed 11 January 2018).

6. Basu S, Glantz S, Bitton A, Millett C. The effect of tobacco control measures during a period of rising cardiovascular disease risk in India: a mathematical model of myocardial infarction and stroke. PLoS Med. 2013;10(7):e1001480. http://dx.doi.org/10.1371/ journal.pmed.1001480 PMID:23874160

7. Levy DT, Cho SI, Kim YM, Park S, Suh MK, Kam S. SimSmoke model evaluation of the effect of tobacco control policies in Korea: the unknown success story. Am J Public Health. 2010 Jul;100(7):1267-73. http://dx.doi.org/10.2105/AJPH.2009.166900 PMID:20466968

8. WHO report on the global tobacco epidemic, 2015. Raising taxes on tobacco. Geneva: World Health Organization; 2015. (http:// www.who.int/tobacco/global_report/2015/en/, accessed 15 May 2017).

9. WHO report on the global tobacco epidemic, 2011. Warning about the dangers of tobacco. Geneva: World Health Organization; 2011 (http://apps.who.int/iris/bitstream/9789240687813/1/44616/10665_eng.pdf, accessed 11 January 2018).

10. WHO report on the global tobacco epidemic, 2013. Enforcing bans on tobacco advertising, promotion and sponsorship. Geneva: World Health Organization; 2013 (http://apps.who.int/iris/bitstream/9789241505871/1/85380/10665_eng.pdf?ua=1, accessed 11 January 2018).

11. WHO Report on the Global Tobacco Epidemic, 2017. Monitoring tobacco use and prevention policies. Geneva: World Health Organization; 2017 (http://apps.who.int/iris/bitstream/-9789241512824/1/255874/10665eng.pdf?ua=1\&ua=1, accessed 11 January 2018).

12. Heydari G, Talischi F, Algouhmani H, Lando HA, Ahmady AE. WHO MPOWER tobacco control scores in the Eastern Mediterranean countries based on the 2011 report. East Mediterr Health J. 2013 Apr;19(4):314-9. PMID:23882955 
13. Heydari G, Ebn Ahmady A, Lando HA, Shadmehr MB, Fadaizadeh L. The second study on WHO MPOWER tobacco control scores in Eastern Mediterranean Countries based on the 2013 report: improvements over two years. Arch Iran Med. 2014 Sep;17(9):621-5. PMID:25204478

14. Khan JA, Amir Humza Sohail AM, Arif Maan MA. Tobacco control laws in Pakistan and their implementation: a pilot study in Karachi. J Pak Med Assoc. 2016 Jul;66(7):875-9. PMID:27427139

15. Lee SG. Assessing impacts of the WHO FCTC on national legislations: a case study of the Republic of Korea. Health Policy. 2017 Jun;121(6):604-12. http://dx.doi.org/10.1016/j.healthpol.2017.02.017 PMID:28410807

16. Hiilamo H, Glantz S. FCTC followed by accelerated implementation of tobacco advertising bans. Tob Control. 2016 Jul;26(4):42833. http://dx.doi.org/10.1136/tobaccocontrol-2016-053007 PMID:27471111

17. Wipfli H. The FCTC Turns 10: Lessons From the Fist Decade. J Epidemiol. 2016 Jun 5;26(6):279-83. http://dx.doi.org/10.2188/jea. JE20160080 PMID:27180935

18. Gravely S, Giovino GA, Craig L, Commar A, D'Espaignet ET, Schotte K, et al. Implementation of key demand-reduction measures of the WHO Framework Convention on Tobacco Control and change in smoking prevalence in 126 countries: an association study. Lancet Public Health. 2017 Apr;2(4):e166-74. http://dx.doi.org/10.1016/S2468-2667(17)30045-2 PMID:29253448

19. Cairney P, Mamudu H. The global tobacco control 'endgame': change the policy environment to implement the FCTC. J Public Health Policy. 2014 Nov;35(4):506-17. http://dx.doi.org/10.1057/jphp.2014.18 PMID:24831675

20. Heydari G, Talischi F, Masjedi MR, Alguomani H, Joossens L, Ghafari M. Comparison of tobacco control policies in the Eastern Mediterranean countries based on tobacco control scale scores. East Mediterr Health J. 2012 Aug;18(8):803-10. http://dx.doi. org/10.26719/2012.18.8.803 PMID:23057368

21. Heydari G, EbnAhmady A, Lando H, Chamyani F, Masjedi MR, Shadmehr M, et al. The third study on WHO MPOWER tobacco control scores in Eastern Mediterranean Countries based on the 2015 report. East Mediterr Health J. 2017 Nov 19;23(9):598-603. PMID:29178116

22. Joossens L, Raw M. The tobacco control scale: a new scale to measure country activity. Tob Control. 2006 Jun;15(3):247-53. http:// dx.doi.org/10.1136/tc.2005.015347 PMID:16728757

23. El-Awa F, Vinayak P, Bettcher D. Moving away from the comfort zone of tobacco control policies to the highest level of implementation. East Mediterr Health J. 2016 Jun 15;22(3):161-2. PMID:27334072

24. Levy DT, Fouad H, Levy J, Dragomir AD, El Awa F. Application of the Abridged SimSmoke model to four Eastern Mediterranean countries. Tob Control. 2016 Jul;25(4):413-21. http://dx.doi.org/10.1136/tobaccocontrol-2015-052334 PMID:26080365

25. Heydari G, Chamyani F, Masjedi MR, Fadaizadeh L. Comparison of tobacco control programs worldwide: a quantitative analysis of the 2015 World Health Organization MPOWER report. Int J Prev Med. 2016 12 12;7(1):127. http://dx.doi.org/10.4103/20087802.195562 PMID:28105292 